\title{
PENGEMBANGAN METODE LATIHAN JUMPING UNTUK MENINGKATKAN VERTICAL JUMP DALAM MELAKUKAN SPIKE BOLA VOLI
}

\author{
Andi Rosadi \\ Universitas Pendidikan Indonesia
}

Email : andirosadi@upi.edu

Abstrak

Kemampuan lompatan atau jumping dalam melakukan teknik spike sangat dominan untuk keberhasillan melakukan spike serta mampu mematikan lawan, oleh karena itu latihan untuk meningatkan vertical jump sangat perlu diperhatikan guna menungjang teknik lompatan atau jumping. Tujuan dalam penelitian ini adalah mana yang lebih efektif dari ke dua jenis bentuk latihan yang diantaranya bentuk latihan plyometric (squat jump) dan bentuk latihan beban (Squat Jump With Weight). Jenis penelitian yang digunakan dalam penelitian ini adalah metode eksperimen. Populasi dalam penelitian ini adalah siswa SMK Sariwangi Kab. Tasikmalaya, sedangkan sampel yang digunakan terdiri dari 24 orang siswa, Sampling yang digunakan dalam penelitian ini yaitu dengan menggunakan teknik purvosif sampling. Berdasarkan pengolahan dan analisis data yang diperoleh, maka hasil penelitian adalah bentuk latihan plyometric (squat jump) mempunyai pengaruh yang berarti terhadap peningkatan vertical jump dapat diterima dan terbukti sesuai dengan kriteria pengambilan keputusan. Begitu juga pada kelompok bentuk latihan beban (Squat Jump With Weight) mempunyai pengaruh yang berarti terhadap peningkatan vertical jump dapat diterima dan terbukti. Nilai dari kelompok bentuk latihan plyometric (squat jump) didapat rata-rata 12,17 dengan sdev dan simpangan baku sebesar 3,24 dan 10,52, sedangkan nilai dari bentuk latihan beban (Squat Jump With Weight) didapat rata-rata didapat rata-rata 11,00 dengan sdev dan simpangan baku sebesar 2,00 dan 4,00,. Pada perhitungan uji perbedaan peningkatan dari kedua kelompok menunjukan hasil yang sama-sama baiknya. Hasil penelitian memberikan implikasi pemilihan bentuk latihan dan prosedur yang tepat dapat memberikan dampak secara signifikan terhadap hasil latihan khususnya terkait peningkatan kemampuan vertical jump dalam melakukan spike bola voli.

Kata Kunci : jumping, plyometric (squat jump), latihan beban (Squat Jump With Weight)

\section{Abstract}

The ability to jump or jump in doing the spike technique is very dominant for the success of doing spikes and being able to kill the opponent, therefore training to increase vertical jump is very important to pay attention to in order to ride the jumping technique or jumping. The purpose of this study is which of the two types of training is more effective, including the plyometric form (squat jump) and the weight training form (Squat Jump With Weight). This type of research used in this study is an experimental method. The population in this study were students of SMK Sariwangi Kab. Tasikmalaya, while the sample used consisted of 24 students, the sampling used in this study was to use purposive sampling technique. Based on the processing and analysis of the data obtained, the results of the study show that the form of plyometric training (squat jump) has a significant effect on increasing the vertical jump which is acceptable and proven in accordance with the decision making criteria. Likewise in the group form of weight training (Squat Jump With Weight) has a significant effect on increasing vertical jump which is acceptable and proven. The value of the plyometric training form group (squat jump) is obtained an average of 12.17 with sdev and standard deviation of 3.24 and 10.52, while the value of the form of 
weight training (Squat Jump With Weight) is obtained on average. average 11.00 with sdev and standard deviation of 2.00 and 4.00 ,. In the calculation of the difference in the increase of the two groups, the results were equally good. The result of this research implies that the selection of the right form of training and procedure can have a significant impact on the results of training, especially in relation to the increase in the ability of vertical jumps in volleyball spikes.

Keywords: Jumping, Plyometric (squat jump), Weight training (Squat Jump With Weight)

\section{PENDAHULUAN}

Perkembangan olahraga dewasa ini semakin pesat menjadikan pemerintah dari berbagai negara terus menerus meningkatkan pembinaan dan pengembangan olahraga serta merupakan bagian upaya peningkatan kualitas manusia di berbagai negara khususnya di Indonesia. Pembinaan prestasi dalam permainan bola voli menuntut suatu usaha secara optimal dari pelakunya, baik bersifat peningkatan aspek fisik, teknik, taktik, maupun mental bermainnya.

Pengembangan potensi peserta didik sebagaimana dimaksud dalam tujuan pendidikan nasional dapat diwujudkan melalui kegiatan ekstrakurikuler yang merupakan salah satu kegiatan dalam program kurikuler. Kegiatan ekstrakurikuler adalah program kurikuler yang alokasi waktunya tidak ditetapkan dalam kurikulum. Pendidikan jasmani di setiap sekolah diharapkan dapat meningkatkan prestasi siswa dalam cabang-cabang olahraga tertentu karena prestasi yang dicapai siswanya dalam cabang olahraga tertentu merupakan kebanggaan sekolah. Begitu pula di SMK Sariwangi Kabupaten Tasikmalaya tempat saya mengajar dan melatih, kami menginginkan siswa kami berprestasi dalam cabang-cabang olahraga tertentu, terutama cabang-cabang olahraga yang dilombakan dalam pekan olahraga dan seni tingkat Sekolah.

Prestasi tidak akan datang dengan sendirinya tanpa melakukan pembinaan, pembinaan tersebit meliputi latihan fisik, teknik, taktik, dan mental secara sistematis dan berulang-ulang dengan menerapkan prinsip-prinsip latihan. Sekaitan dengan hal tersebut latihan merupakan proses serta harus dilakukan guna mencapai tujuan prestasi secara maksimal. practice is one's effort in enhance the repair of organisms and their functions to optimize sports achievements and appearances. The purpose of the practice is to obtain achieves as much as possible, but in the process of implementing the exercise is not quite easy and simple (Bompa \& Buzzichelli, 2018). Maksud dari kutipan tersebut adalah latihan merupakan upaya seseorang dalam meningkatkan perbaikan organisme dan fungsinya untuk mengoptimalkan prestasi dan penampilan olahraga. Tujuan dari latihan 
untuk memperoleh berprestasi semaksimal mungkin, namun dalam proses pelaksaan latihan tidak cukup mudah dan sederhana. Melalui proses latihan serta penguasaan teknik secara sempurna, ditunjang kondisi fisik prima, dan kemampuan untuk menampilkannya dengan taktik serta bervariasi dan didukung oleh semangat juang tinggi, niscaya akan memperoleh prestasi secara maksimal.

Realitas dilapangan yang terjadi pada ekstrakurikuler bola voli di SMK Sariwangi Kabupaten Tasikmalaya, kemampuan dalam proses latihan kurang maksimal. Hal tersebut dibuktikan dari beberapa kompetisi yang dilakukan di tahun 2018-2019 tidak satupun mendapat hasil yang baik, data di lapangan menunjukan bahwa atlet ekstrakurikuler tidak dapat mematikan lawan denggan melakukan teknik serangan dari atas net (jaring) cukup sulit untuk dikuasai oleh para pemain, kesulitan utama untuk melakukan spike bolavoli adalah tingginya net serta melebihi jangkauan lengan para pemain rata-rata relatif memiliki postur tubuh jauh lebih pendek dari tinggi jaring tersebut, sehingga bola serta seharusnya dipukul dari atas jaring tidak dapat dipukul secara maksimal atau menyangkut di net karena power otot tungkai tergolong rendah. Namun demikian keyakinan peneliti hal tersebut bukan suatu masalah besar jika kondisi fisiknya baik. Kondisi demikian membawa implikasi terhadap proses pembinaan prestasi pemain bola voli. Para pemain bola voli harus dibina agar kualitas komponen kebugaran jasmani dan tekniknya prima dan mumpuni.

Teknik dasar spike tidak akan sempurna bilamana tidak didukung oleh komponen kondisi fisik secara baik, kondisi fisik pendukung keterampilan spike terutama dalam aspek lompatan adalah daya ledak (muscular power) otot tungkai. Meningkatkan daya ledak (muscular power) otot tungkai khususnya dalam lompatan spike memang tidak mudah dilatih, terlebih proses latihan terkadang membosankan bagi anak/atlet, terutama proses latihan menggunakan metode latihan monoton atau dengan teknik itu-itu saja tanpa memperhatikan kondisi psikologis anak.

Kemampuan lompatan atau jumping dalam melakukan teknik spike sangat dominan untuk keberhasillan melakukan spike untuk mematikan lawan, oleh karena itu latihan untuk meningatkan vertical jump sangat perlu diperhatikan guna menungjang teknik lompatan atau jumping dalam keberhasilan teknik dasar tersebut. Salah satu penelitian mengungkapkan dalam sebuah artikel "Vertical jump (VJ) occupies a dominant place among the physiological parameters usually used as selection criteria in talent identification and 
selection processes in vooleyball" (Nikolaidis et al., 2017). Maksud kutipan tersebut adalah Vertical jump (VJ) menempati tempat dominan di antara parameter fisiologis serta biasanya digunakan sebagai kriteria seleksi dalam identifikasi bakat dan proses seleksi dalam cabang olahraga bola voli. Sekaitan dengan hal tersebut vertical jump dipandang penting dalam bermain bola voli khususnya dalam melakukan teknik spike. Proses latiahan jumping atau lompatan dalam meningkatkan vertical jump tidak terlepas dalam proses latihan pliometrik untuk membentuk power tungkai serta mumpuni dalam melakukan tolakan dalam melakukan spike. Plyometric training is a type of muscle strength exercise that can improve basic physical strength and it has been extensively studied for the improvement of exercise performance ability. It is an explosive and repetitive rebounding load type exercise that uses the muscles' stretch reflexes and stretchshortening cycles to develop lower extremity muscles (Park et al., 2014)

Maksud dari kutipan diatas latihan plyometric adalah jenis latihan kekuatan otot serta dapat meningkatkan kekuatan fisik dasar dan telah dipelajari secara ekstensif untuk peningkatan kemampuan kinerja otot. Pliometrik sendiri merupakan ledakan eksplosif dan berulang jenis latihan beban serta menggunakan refleks peregangan otot dan siklus peregangan untuk mengembangkan ekstremitas bawah otot. Maka dapat ditarik kesimpulan bahwasannya untuk meningkatan jumping atau lompatan dalam melakukan spike dalam bola voli dibutuhkan proses latihan pliometrik untuk meningkatkan vertical jump dikarenakan komponen tersebut merupakan salah satu komponen dominan guna menentukan keberhasilan dalam lompatan teknik dasar spike. Berlandaskan hasil penelitian yang di terbitkan pada jurnal internasional yang dilakukan oleh Maffiuletti et al., (2002) pelatihan plyometric telah terbukti bermanfaat untuk peningkatan kemampuan lompatan vertikal pada pemain bola voli. Program rangkaian latihan ini menghasilkan peningkatan ekstensor lutut dan kekuatan maksimal fleksor plantar. Adaptasi ini kemudian diikuti oleh peningkatan kemampuan melompat secara umum dan spesifik. Dari hasil penelitian tersebut peneliti beranggapan melalui rangkaian latihan pliometrik dan weight traning diharapkan dapat mampu meningkatkan hasil lompatan vertical jump pada peserta ekstrakurikuler bola voli di SMK Sariwangi Kabupaten Tasikmalaya.

\section{METODE}

Pendekatan penelitian yang digunakan adalah Kuantitatif penelitian yang peneliti gunakan dalam penelitian 
ini adalah metode eksperimen. Metode Eksperimen (mengujicobakan) adalah penelitian untuk menguji variabelvariabel eksperimen efektif atau tidak (Suryana, 2010). Desain penelitian yang digunakan adalah pretest-posttest design. Sampling yang digunakan dalam penelitian ini yaitu dengan menggunakan teknik purvosif sampling dimana peneliti memilih responden berdasarkan pertimbangan tertentu dengan tujuan untuk memperoleh satuan sampling yang memiliki karakteristik atau kriteria yang dikehendaki dalam pengambilan sampel yaitu 24 peserta putra ekstrakurikuler bola voli SMK Sariwangi Kabupaten Tasikmalaya. Instrument yang digunakan adalah Vertical Jump Test dengan menggunakan alat digital vertical jump.

\section{HASIL DAN PEMBAHASAN}

Pada penelitian yang dilakukan oleh peneliti terdapat hasil data yang dapat di reduksi dari ke dua jenis metode latihan yang diantaranya bentuk latihan plyometric (squat jump) dan bentuk latihan beban (Squat Jump With Weight).

Data bentuk latihan tersebut diperoleh berdasarkan prosedur tes dan pengukuran yang dilaksanakan saat pretest dan

\begin{tabular}{|ccccc|}
\hline Variable & \multirow{2}{*}{ Kel } & \multicolumn{2}{c|}{ Nilai Chi-kuadrat } & \multirow{2}{*}{ Ket } \\
\cline { 3 - 4 } & & $\begin{array}{c}\mathrm{X}^{2} \\
\text { hitung }\end{array}$ & $\begin{array}{c}\mathrm{X}^{2} \\
\text { table }\end{array}$ & \\
\hline Pre- & $A$ & 2,63 & 5,99 & Normal \\
Test & $B$ & 2,61 & 5,99 & Normal \\
\hline Post- & $A$ & 0,73 & 5,99 & Normal \\
Test & $B$ & 5,70 & 5,99 & Normal \\
\hline
\end{tabular}

posttest pada kelompok A yaitu bentuk latihan plyometric (squat jump) dan kelompok B bentuk latihan beban (Squat Jump With Weight)

\section{Diagram 1 \\ Perolehan Rata-rata Simpangan Baku dan Variance}

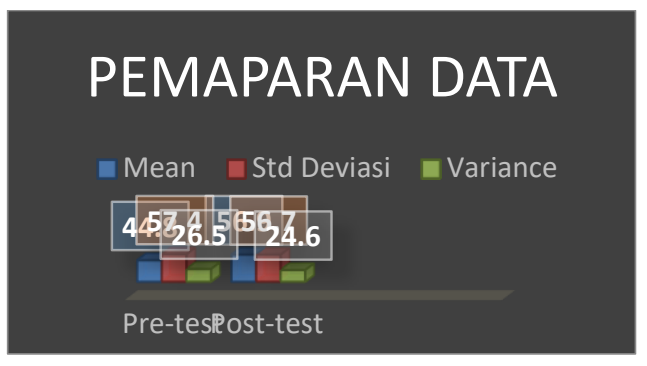

Bedasarkan diagram batang diatas pada hasil rata-rata dapat disimpulkan bahwa untuk latihan plyometric (squat jump) mengalami peningkatan yang lebih signifikan dibandingkan dengan bentuk latihan beban (Squat Jump With Weight). Sebagaimana pada saat pretest bentuk latihan plyometric (squat jump) diperoleh nilai rata-rata $(\boldsymbol{\pi}=44,8)$ dan pada saat posttest diperoleh nilai rata-rata $(\pi=$ 56,9) yang artinya mengalami peningkatan sebesar 12,1. Sedangkan pada kelompok dengan bentuk latihan beban (Squat Jump With Weight) diperoleh nilai rata-rata $(\boldsymbol{\pi}=44,2)$ dan pada saat posttest diperoleh nilai rata-rata $(\boldsymbol{\pi}=55,2)$ yang artinya mengalami peningkatan sebesar 11 . 
Berdasarkan hasil uji normalitas pada tabel diatas dengan menggunakan uji melalui perhitungan statistik $\chi^{2}$ (chikuadrat) pada setiap tes diketahui data pretest dan posttest, dengan taraf nyata $\alpha$ $=0,05 \mathrm{dan} \mathrm{dk}=\mathrm{k}-3$, menunjukan nilai signifikansi lebih besar $\chi^{2}{ }_{(1-\alpha)(k-3)}$ atau $\chi^{2}$ tabel dari daftar chi-kuadrat $\left(\chi^{2}\right)$ atau sama dengan hasil perhitungan statistika $\chi^{2}$ pada ke dua jenis atau kelompok bentuk latihan, maka dapat disimpulkan bahwa data pada kedua kelompok tersebut berdistribusi normal.

Tabel 2

Uji Homogenitas Data

Berdasarkan hasil uji homogenitas

\begin{tabular}{|c|c|c|c|}
\hline $\begin{array}{c}\text { Bentuk Lathan } \\
\text { (Kelompok) } \\
\text { Pre-Test dan } \\
\text { Post-Test }\end{array}$ & $\begin{array}{c}\text { Nilai } \\
F-\text { hitung }\end{array}$ & $\begin{array}{l}F-\text { tabel } \\
\alpha=0,05\end{array}$ & Keterangan \\
\hline A & 1,08 & 2,48 & Homogen \\
\hline$B$ & 0,89 & 2,48 & Homogen \\
\hline
\end{tabular}
perhitungan statistic distribusi $\mathrm{F}$ (Uji F) dari setiap tes diketahui data pretest dan posttest, pada taraf nyata $(\alpha=0,05)$ dan $\mathrm{dk}=\mathrm{n}-1$. Maka data dari kelompok tes itu homogen. Pada ke dua jenis atau kelompok bentuk latihan A dan B, maka dapat disimpulkan bahwa data variabel untuk meningkatkan vertical jump pada kedua kelompok variansi data adalah homogen.

\section{Tabel 3}

Uji t (Paired Sampel t test)

\begin{tabular}{|cccc|}
\hline $\begin{array}{c}\text { Bentuk Lathan } \\
\text { (Kelompok) } \\
\text { Pre-Test dan } \\
\text { Post-Test }\end{array}$ & Nilai & $\begin{array}{c}t \text { - tabel } \\
\alpha=0,05\end{array}$ & Keterangan \\
\hline$A$ & & & \\
$B$ & 6,14 & 2,05 & Signifikan \\
\hline
\end{tabular}

Berdasarkan tabel di atas dapat dilihat bahwa Kelompok A mempunyai pengaruh yang berarti terhadap peningkatan vertical jump dapat diterima dan terbukti Begitu juga pada kelompok B mempunyai pengaruh yang berarti terhadap peningkatan vertical jump dapat diterima dan terbukti. Maka dapat disimpulkan bahwa terdapat pengaruh yang signifikan kelompok A bentuk latihan plyometric (squat jump) dan kelompok B bentuk latihan beban (Squat Jump With Weight) terhadap peningkatan vertical jump.

Tabel 4

Uji Perbedaan Peningkatan Kelompok A dan Kelompok B

\begin{tabular}{|cccc|}
\hline $\begin{array}{l}\text { Kel } \\
\text { Sampel }\end{array}$ & thitung & $\mathbf{t}_{\text {tabel }}$ & Keterangan \\
& & & \\
\hline$A$ & \multirow{2}{*}{ (2,06 } & 2,05 & $\begin{array}{c}\text { Tidak Terdapat } \\
\text { Perbedaan Yang } \\
\text { Signifikan }\end{array}$ \\
& & & \\
\hline
\end{tabular}

Pada perhitungan uji perbedaan peningkatan dari kedua kelompok bentuk latihan plyometric (squat jump) dan bentuk latihan beban (Squat Jump With Weight) untuk meningkatkan vertical jump ini menunjukan bahwa $t_{-h i t u n g}$ lebih kecil dari $t_{-t a b e l}$. Ini berarti sesuai dengan kriteria diatas bahwa Tidak terdapat 
perbedaan pengaruh yang signifikan antara kelompok bentuk latihan plyometric (squat jump) dan bentuk latihan beban (Squat Jump With Weight) untuk meningkatkan vertical jump. $t_{\text {-hitung }}$ berada di luar penerimaan hipotesis, jadi hipotesis nol (Ho) diterima dan hipotesis kerja ditolak. Dengan demikian kedua bentuk latihan plyometric (squat jump) dan bentuk latihan beban (Squat Jump With Weight) untuk meningkatkan vertical jump samasama baiknya.

Berdasakan hasil pengujian hipotesis diperoleh informasi bahwa dapat ditarik kesimpulan tidak terdapat perbedaan pengaruh yang signifikan antara kelompok bentuk latihan plyometric (squat jump) dan bentuk latihan beban (Squat Jump With Weight) untuk meningkatkan vertical jump. Dari kedua bentuk latihan tersebut tidak terdapat perbedaan pengaruh yang berarti, atau dengan kata lain kedua bentuk latihan tersebut sama efektifnya atau sama baiknya dalam meningkatkan power otot tungkai. Adanya peningkatan power otot tungkai akibat dari kedua bentuk latihan tersebut disebabkan oleh Pemberian latihan dari kedua kelompok dalam penelitian ini dilakukan secara sistematis, berulang-ulang, terprogram, dan terencana. Hal ini secara kuat memungkinkan terjadinya peningkatan power otot tungkai. Pada saat pergerakan latihan tersebut otot-otot tungkai akan berkontraksi dengan submaksimal karena otot yang akan dikontraksikan terlebih dahulu diregangkan sehingga mendorong tubuh ke atas. Pada saat jongkok pun otot-otot tungkai akan berkontraksi secara submaksimal secara isometrik untuk menahan tubuh supaya tidak terjatuh. Setelah jongkok di posisi yang stabil, kemudian otot-otot tungkai dengan cepat berkontraksi lagi untuk kembali berdiri (squas) lagi sehingga terjadi gerak yang kontinyu. Dengan demikian, pemberian latihan dengan gerak yang sistematis dan dilakukan secara berulang-ulang akan memberikan kontribusi kepada otot sehingga terjadi peningkatan kekuatan otot tungkai. Kedua bentuk latihan tersebut sama efektifnya karena kedua bentuk latihan ini mempunyai karakteristik yang sama. Gerakan-gerakan pada proses latihan tersebut jika dilakukan secara sistematis dan berulang, dengan menerapkan prinsip latihan, maka gerakan-gerakan tersebut menurut (Bompa \& Buzzichelli, 2018) akan mengakibatkan perubahan pada sistem otot, baik secara anatomis maupun biokemis yang langsung berdampak pada peningkatan kualitas fisiologisnya. Jadi suatu hal yang tidak mungkin terjadi peningkatan kekuatan, daya ledak otot, dan daya tahan otot, tanpa didahului perubahan positif dari 
sistem otot baik secara anatomis dan biokemis.

\section{KESIMPULAN}

Bentuk latihan plyometric (squat juтр) mempunyai pengaruh yang berarti terhadap peningkatan vertical jump dapat diterima dan terbukti sesuai dengan kriteria pengambilan keputusan. Begitu juga pada kelompok bentuk latihan beban (Squat Jump With Weight) mempunyai pengaruh yang berarti terhadap peningkatan vertical jump dapat diterima dan terbukti. Maka dapat disimpulkan bahwa terdapat pengaruh yang signifikan bentuk latihan plyometric (squat jump) dan bentuk latihan beban (Squat Jump With Weight) terhadap peningkatan vertical jump. Kemudian Pada perhitungan uji perbedaan peningkatan dari kedua kelompok bentuk latihan plyometric (squat jump) dan bentuk latihan beban (Squat Jump With Weight) untuk meningkatkan vertical jump ini menunjukan tidak terdapat perbedaan pengaruh yang signifikan antara kelompok bentuk latihan plyometric (squat jump) dan bentuk latihan beban (Squat Jump With Weight) untuk meningkatkan vertical jump. Dengan demikian kedua bentuk latihan plyometric (squat jump) dan bentuk latihan beban (Squat Jump With Weight) untuk meningkatkan vertical jump samasama baiknya.
Untuk melakukan latihan latihan beban (Squat Jump With Weight) diprasyaratkan atlet telah memiliki base strength (dasar kekuatan) yang baik, sehingga pada saat melaksanakan bentuk latihan tersebut menjadi optimal. Pada saat treatment latihan, dimungkinkan ada beberapa protokol latihan yang tidak dilakukan, karena untuk mencapai hasil masimal dari latihan beban (Squat Jump With Weight) harus memperhatikan beberapa hal, sepertinya saat melakukan latihan beban, diantaranya: kecepatan lompatan, teknik lompatan, dan interval istirahat yang tidak dipenuhi secara benar. Interval istirahat menjadi penting, pada program spepeti itu dilakukan ICRI 3 menit dan latihan power atlet tidak boleh dalam kondisi kelelahan, dengan kualitas gerak menjadi utama, seperti Matthews and Comfort menekankan bahwa ketika menerapkan CT untuk meningkatkan speed dan strength, bahwa atlet tidak boleh lelah, sesi tidak boleh menyebabkan kelelahan metabolisme, dan penekanannya adalah pada kecepatan tinggi / kualitas gerakan (Jones \& Lees, 2003)

\section{DAFTAR PUSTAKA}

Bompa, T. O., \& Buzzichelli, C. (2018). Periodization-: $\quad$ theory and methodology of training. Human kinetics.

Jones, P., \& Lees, A. (2003). A biomechanical analysis of the acute 
effects of complex training using lower limb exercises. Journal of Strength and Conditioning Research, 17(4), 694-700.

Maffiuletti, N. A., Dugnani, S., Folz, M., Pierno, E. D. I., \& Mauro, F. (2002). Effect of combined electrostimulation and plyometric training on vertical jump height. Medicine \& Science In Sport \& Exercise, https://doi.org/10.1249/01.MSS.00 00031481.28915 .56

NASIONAL, U.-U. R. I. N. 20 T. 2003 T. S. P. (2003). UNDANGUNDANG REPUBLIK INDONESIA NOMOR 20 TAHUN 2003 TENTANG SISTEM PENDIDIKAN NASIONAL. 1, 6-8. https://doi.org/10.16309/j.cnki.issn .1007-1776.2003.03.004

Nikolaidis, P. T., Gkoudas, K., Afonso, J., Clementesuarez, V. J., Knechtle, B., Kasabalis, S., Kasabalis, A., Douda, H., Tokmakidis, S., \& Torres-Luque, G. (2017). Who jumps the highest? Anthropometric and physiological correlations of vertical jump in youth elite female volleyball players. Journal of Sports Medicine and Physical Fitness, 57(6), 802-810. https://doi.org/10.23736/S00224707.16.06298-8

Park, G. D., Lee, J. C., \& Lee, J. (2014). The effect of low extremity plyometric training on back muscle power of high school throwing event athletes. Journal of Physical Therapy Science, 26(1), 161-164. https://doi.org/10.1589/jpts.26.161

Suryana. (2010). Metodologi penelitian.

Tentang, p. P. R. I. N. 19 t. 2005, \& pendidikan, s. N. (2005). Peraturan pemerintah republik indonesia nomor 19 tahun 2005 tentang standar nasional pendidikan dengan. 12 Suppl 1(9), 1-29. https://doi.org/10.1007/978-1-

4614-7990-1 